\title{
Somatic Cell Genetics
}

National Cancer Institute

\section{Source}

National Cancer Institute. Somatic Cell Genetics. NCI Thesaurus. Code C19037.

Various methods for gene function studies that rely on the use of cells in culture. 